\title{
Developing health accounts following SHA 2011: a situational analysis of countries in WHO Eastern Mediterranean Region
}

\author{
Nila Nathan, ${ }^{1}$ Ilker Dastan ${ }^{1}$ and Awad Mataria ${ }^{1}$
}

${ }^{1}$ World Health Organization Regional Office for the Eastern Mediterranean, Cairo, Egypt (Correspondence to: N. Nathan: nilaanathan@gmail.com).

\begin{abstract}
Background: National health accounts provide data for health-financing policy analysis, reforms and strategies to attain national health development goals and objectives such as universal health coverage. However, in the World Health Organization (WHO) Eastern Mediterranean Region there are many challenges, making it difficult for health accounts teams to provide timely reports and for policy-makers to use them to inform policy change.

Aim: To undertake a situational analysis of health accounts in the Region and assess the health accounts production process. Additionally, the study looked at challenges facing health accounts teams in institutionalizing the health accounts process.

Methods: The WHO Regional Office for the Eastern Mediterranean has been conducting country missions to its 22 countries to assist health accounts teams and assess the status of health accounts production and institutionalization. A survey administered at a regional training workshop in October 2018 examined the challenges and successes in health accounts production.

Results: Three countries in the Region produce annual health accounts but most take several years between reports. Only 55\% of the countries use System of Health Accounts (SHA) 2011 methodology while 27\% still use SHA 1.0. The main challenges facing countries include a high turnover of employees involved in health accounts production, and time lag of data. Notable successes include policy changes based on health accounts findings.

Conclusions: Few countries in the Region produce annual health accounts and many still use SHA 1.o. The commitment of a country's top management is vital to ensure successful health accounts production.

Citation: Nathan N; Dastan I; Mataria A. Developing health accounts following SHA 2011: a situational analysis of countries in WHO Eastern Mediterranean Region. East Mediterr Health J. 2020;26(7):810-819. https://doi.org/10.26719/emhj.20.031

Received: 31/03/19; accepted: 04/11/19

Copyright (C World Health Organization (WHO) 2020. Open Access. Some rights reserved. This work is available under the CC BY-NC-SA 3.0 IGO license (https://creativecommons.org/licenses/by-nc-sa/3.o/igo)
\end{abstract}

\section{Introduction}

Health accounts (HA) are an important tool to map the flow of funds in the health sector and can provide countries with the evidence they need for reform. Better understanding of how funds are allocated in the health sector can help policy-makers and senior management locate problems in the health sector. HA also provide data on how funds are raised and used, and are useful to foster routine questioning and analysis of trends in health system resources. They enable us to know if the allocation of resources is effective or not, making HA play a vital role in evidence-based decision-making (1). HA are valuable to policy-makers and senior management, as well as researchers, showing where priorities should be in health systems research (2). The final product of a country's health accounts are called national health accounts (NHA) (3).

NHA show a triaxial framework of healthcare financing using the International Classifications for Health Accounts (ICHA). Specifically, the 3-core classifications are the functions of health care (ICHA$\mathrm{HC}$ ), health-care provision (ICHA-HP) and financing schemes (ICHA-HF). By definition, provision equals consumption and is financed. System of Health Accounts (SHA) 2011 expands on this initial framework to provide more detailed coverage by including consumption by population groups (divided by age, disease burden, income quintile, etc.), factors of provision, and revenues from financing schemes. Two other new additions are global burden of disease (GBD) classification and current health expenditure. GBD classification cross-references expenditure on diseases with sociodemographics, while current health expenditure represents final consumption excluding capital expenditure from total health expenditure, which is now separately tracked. Capital expenditure is also tracked separately (4). Using GBD to classify expenditure with characteristics, such as age, sex or socioeconomic status will lead to greater policy application of interest to a wider stakeholder group.

In the World Health Organization (WHO) Eastern Mediterranean Region, there are still only limited data to inform policy-makers about the health sector. The Region includes 10 of the world's 35 most fragile and conflict-affected states, as defined by the World Bank, based on financial and security status $(5,6)$. It is important for countries to institutionalize a process for producing HA, preferably using the latest SHA 2011 methodology, so that results can be generated on a regular basis and identify needs. SHA 2011 makes it easier for countries to map expenditure regularly in the appropriate categories and to track and code disease expenditure. It also offers 
an international standard framework that helps ensure consistency and comparability of results (7).

The purpose of the present study was to undertake a situational analysis of HA in the Region, gathering data on the methods that HA teams use and the staff and departments involved in HA production. We also looked at the main challenges NHA teams faced and what prevented some from switching to SHA 2011.

\section{Methods}

WHO Regional Office for the Eastern Mediterranean has been engaged in technical cooperation with countries to develop, review and validate their HA data, and provide technical consultation on updating previous health expenditure databases. In addition, during a regional training workshop on HA in Tunis, Tunisia, on 21-25 October 2018, WHO staff conducted face-to-face interviews with $\mathrm{HA}$ team members and the main focal persons on HA production. One to three official HA focal persons from each member state were invited to share the successes and challenges they encountered during the production of HA. The survey was prepared based on several international surveys on HA using the format of SWOT (strengths, weaknesses, opportunities, and threats) analysis and several international HA experts were consulted for the validity and reliability of the survey. Pilot interviews with 2 member states were also conducted to revise the questionnaire. The first part of the survey was about the methodology of data collection and information about the country's HA team, while the second part invited team members to discuss the strengths and weaknesses in HA production as well as any future opportunities to help the process, and the priorities of what needs to be addressed. All the interviews were recorded, transcribed into an Excel data sheet, and validated by focal persons in WHO country offices. Sixteen of the 22 member states participated in the interviews but some were not able to attend the regional workshop. The member states whose experts participated in the survey were Afghanistan, Bahrain, Egypt, Islamic Republic of Iran, Iraq, Jordan, Lebanon, Libya, Morocco, Oman, Palestine, Saudi Arabia, Sudan, Syrian Arab Republic, Tunisia, and the United Arab Emirates (UAE). See the Appendix for the questionnaire used in the study.

\section{Results}

The countries of the WHO Eastern Mediterranean Region have varying levels of experience in the production of HA. About $55 \%$ of the countries currently use SHA $2011,27 \%$ of the countries use SHA 1.0 and $18 \%$ have not yet started HA production (Figure 1). Before 2011, some HA teams in the Region such as those in Egypt, Lebanon, Morocco, Jordan and Tunisia already had experience from using SHA 1.0, with Egypt being one of the first lower-middle-income countries to have started the HA production process.

Afghanistan, Egypt, Sudan and Tunisia use SHA 2011 with diseases; Bahrain, Djibouti, Iraq, Jordan, Oman,
Figure 1 Percentage of countries in the World Health Organization Eastern Mediterranean Region currently using SHA 2011 versus SHA 1.0.

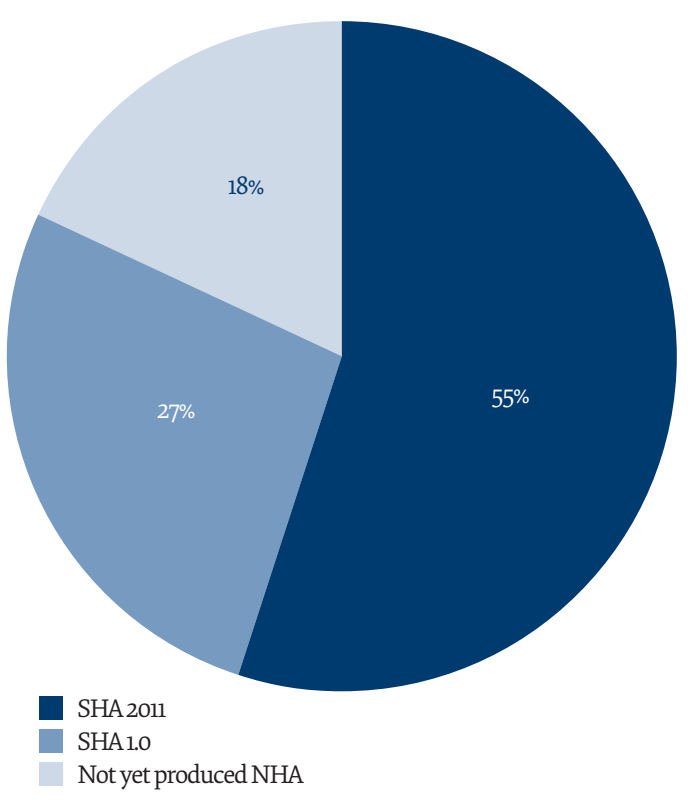

Palestine, Qatar and Saudi Arabia currently use SHA 2011 without diseases; and the Islamic Republic of Iran, Kuwait, Lebanon, Morocco, Pakistan and Yemen still use SHA 1.o. Libya, Somalia, Syrian Arab Republic and UAE have not yet started NHA. Some of the Emirates, such as Dubai, have created sub-NHA (8). Figure 2 illustrates how often each country produces HA and the methodology used.

The Islamic Republic of Iran, Jordan and Pakistan are currently the only member states that have an institutionalized HA process. Even though Bahrain and Oman have yet to institutionalize the HA process, their governments are committed to HA institutionalization in the future, and have set up a timeline and plan for HA production.

Many stakeholders are involved in producing HA. For the majority, the Ministry of Health is the main entity in charge of the country's HA production. In a few countries, an institution has been established to set the health reform goals, and is responsible for regular HA production, such as the High Health Council in Jordan and the Ministry of Public Health in Qatar. In some countries, such as Djibouti and Sudan, there is collaboration between the Ministry of Health and other ministries and government institutions. Although countries successfully collaborate with stakeholders throughout the process, many challenges impede the institutionalization of the regular production of HA; for example, high employee turnover, issues with data collection and analysis, and lack of government commitment. These issues were highlighted during the interviews conducted at the workshop.

Afghanistan, Iraq, Jordan, Lebanon, Sudan and UAE were all found to have high turnover rates in their HA 
Figure 2 How often countries in the World Health Organization Eastern Mediterranean Region produce national health accounts and which methodology they have used

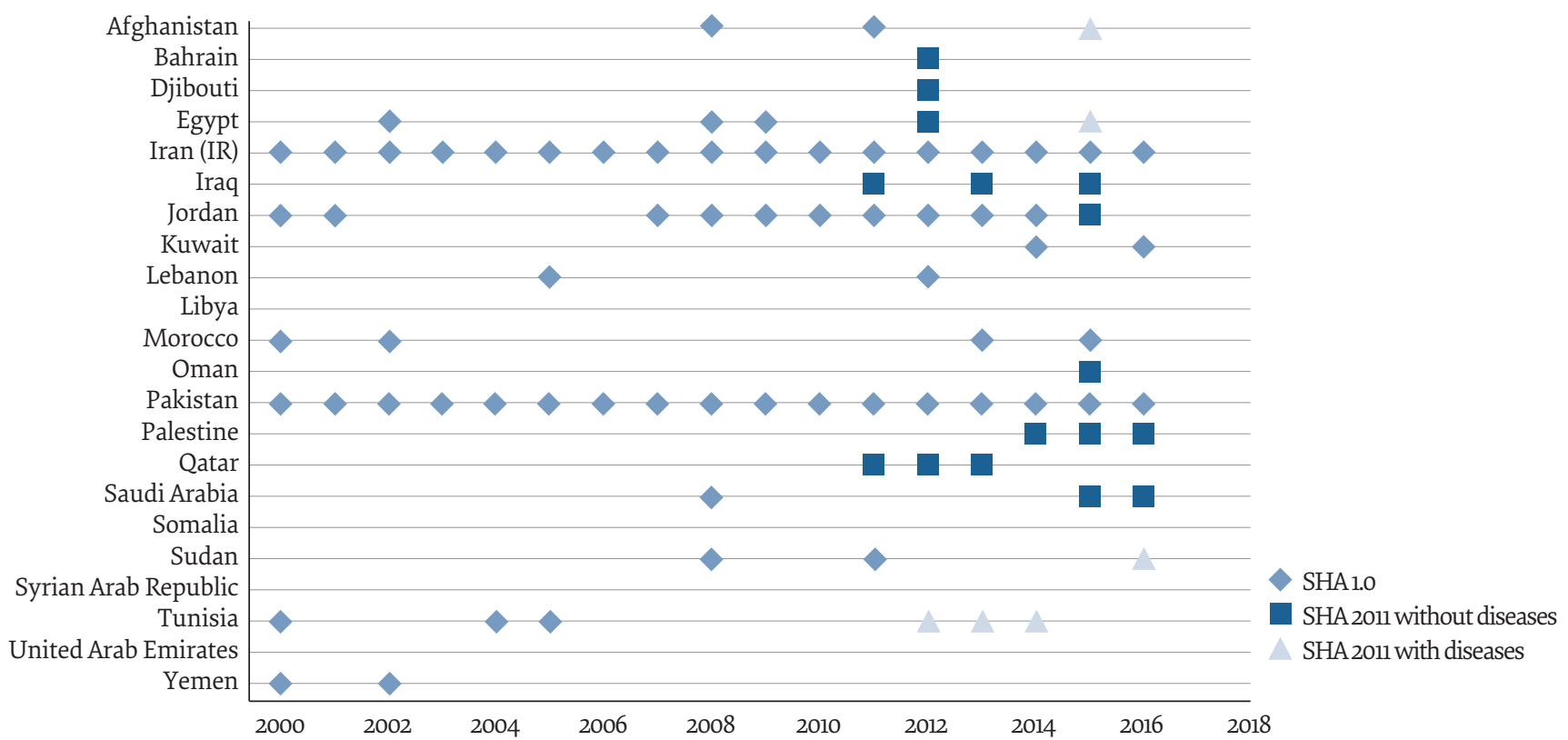

teams. In Iraq, high turnover among policy-makers made it challenging to raise stakeholders' awareness of the importance of HA and to facilitate data collection. The combination of turnover among policy-makers and low interest from stakeholders made the HA production process particularly difficult. For instance, Jordan has a difficult time in institutionalization due to high turnover of the HA team with about 3 or 4 members changing annually. In addition, most countries need help creating better capacity building, providing better training, and support from the government financially. To have a sustainable HA production, it is vital to have a consistent team. Most countries' teams only work part time, with the lack of staff lengthening the production process. It took about 1 year to produce an HA report for most countries in the Region, while Afghanistan and Morocco took 2 or more years.

While data were available, it was challenging to retrieve them in a timely manner and to obtain quality data. This reduced the potential attraction and value of $\mathrm{HA}$ to donors and policy-makers because reports were often based on data from several years ago. Egypt, Morocco, Tunisia and Yemen all had time lags in their data (9). The Islamic Republic of Iran, Oman, Pakistan and Palestine had recent data (10). Having to choose between time and accuracy affected the quality of HA, and progress on this issue requires more resources and political will $(7,11)$. It was found that Yemen lacked quality data and when they did have data, they were delivered late. Collaboration with the stakeholders to obtain data also proved to be a challenge for many countries. Bahrain, Islamic Republic of Iran, Oman and Pakistan, however, did well in collaborating with stakeholders and ministries to obtain the data they needed for policy-makers $(12,13)$.
Another challenge many countries mentioned was that the Health Accounts Production Tool (HAPT), which takes HA teams through the entire production process, as well as increasing capacity for HA production, was not user friendly (14). Egypt stated that the HAPT process was lengthy and the team often had to make secondary sheets or nonstandard Excel sheets to obtain the data that they needed to fulfil the core SHA aggregates. In Palestine, while team members were generally able to use HAPT, they faced difficulties in importing their data into the program. The challenges regarding HA production are shown in Appendix Table 1.

HA teams are either sponsored by government or WHO or both, or funded by donors. Egypt and Tunisia were fully sponsored by WHO while the Islamic Republic of Iran, Iraq, Jordan, Libya, Oman, Palestine and Saudi Arabia were fully sponsored by their governments. Bahrain was sponsored by both WHO and its government. Afghanistan, Djibouti and Sudan were primarily funded by donors with some government funding. This lack of government commitment and having to rely on external funding greatly affected the sustainability of HA production. Appendix Table 2 shows which entities funded HA production in each country.

The main successes found were reforms based on HA findings. When government commitment was strong, results generated from HA helped change countries' policies. For example, from Egypt's second NHA, the country developed the Family Health Model and in 2016, Egypt spent 10 billion Egyptian pounds in their ambulance sector. In Jordan, a health sector reform was put in place in 1995 because of results from their 1994 HA. In Lebanon, the results of the HA report led to the Ministry of Public Health earmarking budgets 
for additional health resources (15). According to the participants of the survey during the regional training workshop, in Afghanistan, HA reports convinced policymakers to rebuild the health sector and in 2016, the Ministry of Health decided to develop an expenditure system to collect expenditure data, allowing the HA team direct access to data. In Bahrain, Egypt, Morocco, Palestine and Sudan, out-of-pocket expenditure was found to be too high. The World Health Report 2010 noted that it is difficult to get close to universal health coverage at less than $4-5 \%$ of Gross Domestic Product, and such a ratio is required to limit the proportion of out-of-pocket payments to $20 \%$ of current health expenditure, which in turn is needed to achieve low rates of catastrophic and impoverishing health expenditure (16). According to the HA workshop interviews, policy-makers have reformed their countries' health insurance policies to provide universal health coverage and protect households from financial catastrophe.

According to survey respondents, another success mentioned was data collection. Many countries could collect data from multiple sources. In Palestine, data collection was said to be standardized and they collected from several sources such as surveys and administrative records, and estimated household survey data from the Expenditure and Consumption Survey by the Palestine Central Bureau of Statistics. Afghanistan was able to gather about $85 \%$ of the data they needed, other than data from the military because it had its own structure and setting. In Egypt, they had a consistent HA team that made the process run smoother, and they are currently trying to enhance the data collection process by collecting from more than one source. Officials in Bahrain, Egypt, Oman and Saudi Arabia reported that they could successfully collect data from all parts of the health sector except for the private sector. However, many of the countries were working with stakeholders to change this.

\section{Discussion}

One of the priorities for health accounting in the WHO Eastern Mediterranean Region is for all countries to produce yearly HA through a well-institutionalized process. As shown above, the countries of the Region have widely varying levels of experience of producing HA, and some have yet to produce any. The next priority is for countries to switch to the SHA 2011 methodology, especially with diseases. Most countries, who still use SHA 1.0, mentioned the importance of switching to SHA 2011 as it is more useful for policy-makers.

Although 12 countries have already switched to using SHA 2011, regardless of which methodology the countries are using, most countries still do not have an institutionalized process for their HA in place. While there are many factors that contribute to this, one of them was the fact that many countries in the region faced high staff turnover rates. It was found that Afghanistan, Lebanon and UAE had difficulties in recruiting and retaining employees. The causes of high turnover included meagre financial incentives, poor working environment, low job satisfaction, and the fact that qualified professionals could find better opportunities in other countries (17-19). In order to have sustainable and institutionalized HA production, it is important to have a consistent team. To make this happen and prevent the brain drain, more funds should be allocated to healthcare employees involved in HA production and provide them with better facilities. The need to repeatedly train new staff due to the high turnover also likely leads to increased costs in institutionalizing and producing HA.

Many countries found that HAPT was not a userfriendly tool, which deterred them from switching to SHA 2011. Although HAPT provides many benefits, the downside is that survey templates for the data sources as donors, nongovernmental organizations, employers, and insurance are too long, and some countries do not fill them in. These templates need to be redesigned, or made shorter, focusing on the important data.

Although countries generally had access to many sources of data, time lags were a major issue. An active steering committee and engaged stakeholders are crucial to oversee timely data collection from each sector and solve problems raised by HA teams. It is important to institutionalize a system for data collection. In most countries of the Region, data are limited, restricted and of poor quality. Rahim et al. reported that data for public health expenditure were available for under half the countries of the Region, and most data were estimated or outdated (20). Saleh et al. found that each country's data are kept private or there are strict guidelines when it comes to sharing the information (10). The Region could benefit when it comes to policy planning by sharing data among the countries. This lack of cooperation also makes it difficult for HA teams to gather data. Although this has started to change, stronger efforts should be made to bring about more transparency and give everyone access to quality data in the Region. It is important, however, to focus on making the current system stronger, more efficient, and more transparent, rather than building an entire new data collection system.

HA create evidence for countries based on total health expenditures, health prioritization, and fiscal space. Fiscal space for health is a government's ability to spend more on the health sector without affecting other sectors or endangering the economy (21). Asbu et al. found that if a government spends $<20 \%$ of its general expenditure on health, it indicates that fiscal capacity for the country is low (22). However, if one looks at the Global Health Expenditure Database, many countries spend on health $10-15 \%$ of general government expenditure, or even less. How much a country spends on health also depends on political will and government priority given to health. According to the WHO report on "New Perspectives on Global Health Spending for Universal Health Coverage", low-income countries often obtain $33 \%$ of their funding from external resources. However, instead of the governments using the money to invest more in their health sector, this only ends up with them allocating 
the money to areas other than the health sector (23). In Djibouti, for every 100 Djibouti francs that are invested into the health sector, 27 of them come from foreign funding. External funding can be unreliable and one cannot depend on it, hence people in Djibouti are trying to convince the government to put more into funding the health sector to become more self-sufficient (24). For some countries, such as Somalia and Sudan, it is difficult to obtain external funding in the first place. The African Development Bank provides Sudan with a limited number of loans, and Somalia is not even eligible due to war and political instability (25). WHO does its best to provide financial support, but it is important for governments to realize the importance of HA to create sustainability regarding $\mathrm{HA}$ and hence institutionalize the process in the country.

In many countries, government commitment is still lacking. Governments must be made aware of the importance of the production of HA and be committed to improving their countries' healthcare systems based on evidence. More accountability and transparency will facilitate the need for production of HA, and in turn lead to implementation of reform based on the results (26). These results cannot be achieved without the cooperation of top management and policy-makers.

Limitations of the study included the fact that some countries were not able to fully discuss the challenges posed by their governments' restrictive data laws. In addition, during the regional training workshop on health accounts in Tunisia, we were only able to interview 16 of the Region's 22 countries.

\section{Conclusions}

Only 3 countries in the Region have been producing regular HA and 6 are just beginning to produce regular HA. It is vital that all countries in the Region begin to produce annual HA. There are many stakeholders involved in the process with the main entities being the Ministry of Health, Ministry of Finance, High Health Council and Department of Statistics. However, many countries still face significant challenges in institutionalizing the production process, including high employee turnover, data collection difficulties and a lack of commitment from government. Once the process is institutionalized, all countries in the Region should move to the new SHA 2011 methodology, and especially to SHA 2011 with diseases, to track disease expenditure in each country and provide better coverage.

\section{Acknowledgement}

The authors would like to thank all the focal persons of the NHA teams for participating in the survey during the Regional Health Accounts Workshop. We also thank Dr. Mahmoud Farag as he was an integral part in collecting data from the HA teams during missions as well as during the workshop. Additionally, he and Dr. Cor van Mosseveld provided us with invaluable information and were always helpful and supportive.

Funding: World Health Organization.

Competing interests: None declared.

\section{Élaboration de comptes de la santé conformément au SCS 2011 : analyse de la situation des pays de la Région OMS de la Méditerranée orientale \\ Résumé}

Contexte : Les comptes nationaux de la santé fournissent des données utiles pour l'analyse des politiques de financement de la santé et la mise en place de réformes et de stratégies visant à atteindre les cibles et les objectifs nationaux de développement dans le domaine de la santé, tels que la couverture sanitaire universelle. Cependant, face aux nombreux défis auxquels se heurte la Région OMS de la Méditerranée orientale, les équipes responsables des comptes de la santé ont des difficultés à soumettre leurs rapports en temps voulu et les responsables de l'élaboration des politiques peinent à utiliser ces rapports pour éclairer les changements de politiques.

Objectifs : Entreprendre une analyse situationnelle des comptes de la santé dans la Région et évaluer le processus de production de ces comptes. En outre, l'étude a examiné les défis auxquels sont confrontées les équipes responsables des comptes de la santé dans l'institutionnalisation du processus d'établissement de ces comptes.

Méthodes : Le Bureau régional de l'Organisation mondiale de la Santé pour la Méditerranée orientale a mené des missions dans les 22 pays de la Région afin de prêter assistance aux équipes responsables des comptes de la santé et d'évaluer l'état de la production et de l'institutionnalisation de ces comptes. Une enquête menée lors d'un atelier de formation régional en octobre 2018 a permis d'examiner les défis et les succès rencontrés dans la production de comptes de la santé.

Résultats : Trois pays de la Région produisent des comptes de la santé chaque année, tandis que la majorité des autres pays établissent des rapports espacés de plusieurs années. Seuls $55 \%$ des pays utilisent la méthodologie préconisée par le Système de comptes de la santé (SCS) 2011 et 27\% suivent encore le modèle du SCS 1.0. 
Les principaux problèmes auxquels se heurtent les pays sont la forte rotation des employés chargés de la production de comptes de la santé et le décalage temporel des données. Parmi les réussites qui méritent d'être notées, l'on peut citer les changements de politiques qui ont été inspirés par les résultats des comptes de la santé.

Conclusions : Peu de pays de la Région produisent des comptes de la santé chaque année et beaucoup suivent encore les recommandations du SCS 1.0. Il est capital que les pouvoirs publics des pays prennent des engagements au plus haut niveau pour garantir le succès de la production de ces comptes.

\section{إعداد الحسابات الصحية عقب نظام الحسابات الصحية 2011: تحليل الوضع في البلدان بإقليم منظمة الصحة العالمية لشرق المتوسط نيلا ناثان، ألكر دشتان، عوض مطرية

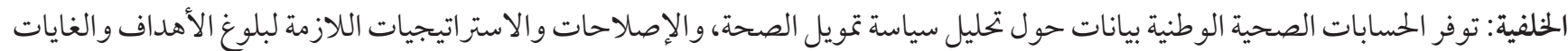

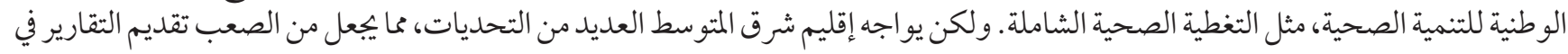

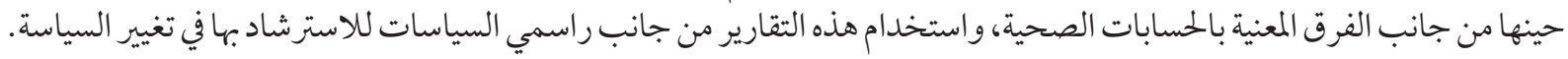

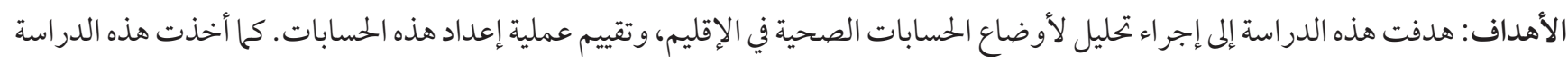

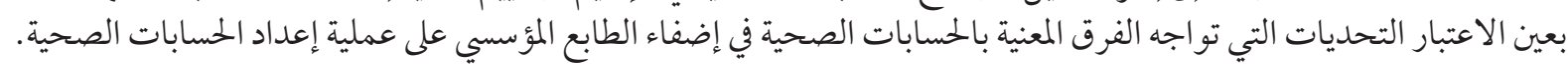

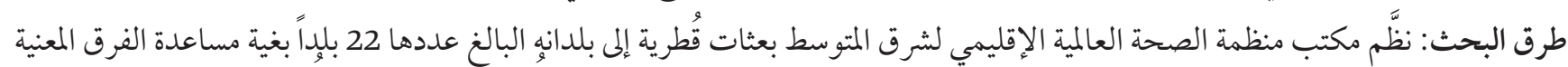

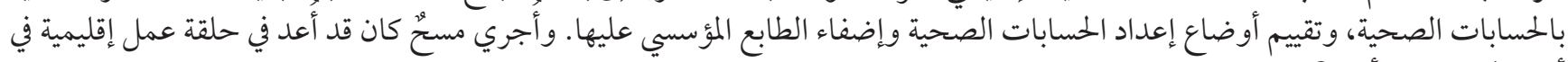

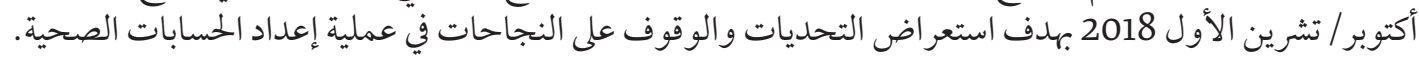

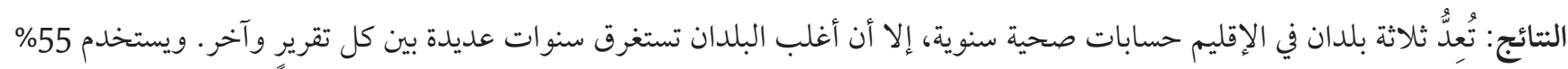

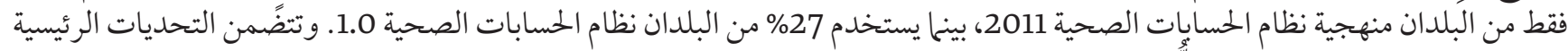

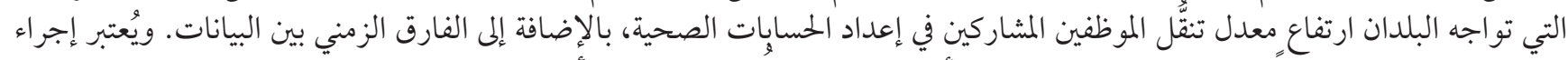

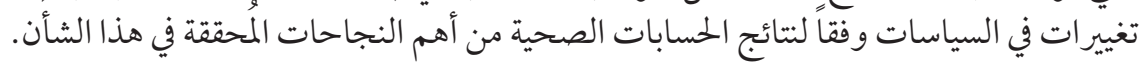

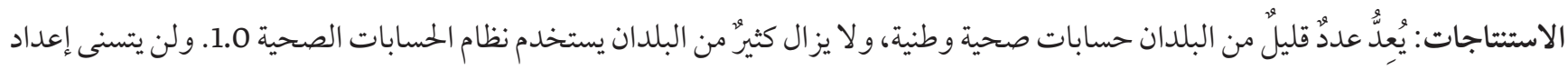

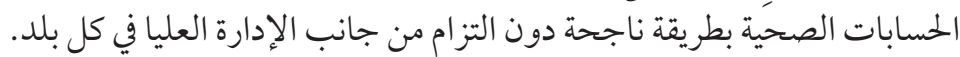

\section{References}

1. A System of Health Accounts manual. OECD, Eurostat, World Health Organization; 2011 (https://www.who.int/health-accounts/ methodology/sha2011.pdf, accessed 30 January 2020).

2. El-Jardali F, Makhoul J, Jamal D, Ranson MK, Kronfol NM, Tchaghchagian V. Eliciting policymakers' and stakeholders' opinions to help shape health system research priorities in the Middle East and North Africa region. Health Policy and Planning. 2010 Jan; 25(1):15-27. https://doi.org/10.1093/heapol/czp059 PMID:19948770

3. Rannan-Eliya RP, Berman P. National health accounts in developing countries: improving the foundation; 1993

4. Cogswell H, Connor C, Dereje T, Kaplan A, Nakhimovsky S. System of Health Accounts 2011: what is SHA 2011 and how are SHA 2011 data produced and used? USAID; 2013 (https://www.hfgproject.org/system-health-accounts-sha-2011-data-produced-used/, accessed 30 January 2020).

5. Fragile and conflict-affected states. Health and WHO. Geneva: World Health Organization; 2017 (WHO/CCU/17.06) (https://apps. who.int/iris/bitstream/handle/10665/255801/WHO-CCU-17.06-eng.pdf;jsessionid=A3DEE40686291FFB98F573D84E1C764B?sequence $=1$, accessed 30 January 2020).

6. Haar RJ, Rubenstein LS. Health in post-conflict and fragile states. Washington DC: United States Institute of Peace; 2012 (https:// www.usip.org/publications/2012/01/health-post-conflict-and-fragile-states, accessed 30 January 2020).

7. van Mosseveld C, Hernández-Peña P, Arán D, Cherilova V, Mataria A. How to ensure quality of health accounts. Health Policy. 2016 May;120(5):544-51. doi.org/10.1016/j.healthpol.2016.03.009 PMID:27048758

8. Hamidi S. Evidence from the national health account: the case of Dubai. Risk Manag Healthc Policy. 2014 Sep 24;7:163-75. http:// dx.doi.org/10.2147/RMHP.S69868 PMID:25285027

9. Yemen national health accounts estimates 2003. Partners for Health Reformplus; 2006 (http://www.phrplus.org/Pubs/Tech103_ fin.pdf, accessed 30 January 2020). 
10. Saleh SS, Alameddine MS, El-Jardali F. The case for developing publicly-accessible datasets for health services research in the Middle East and North Africa (MENA) region. BMC Health Serv Res. 2009 Oct 29;9(1):197. http://dx.doi.org/10.1186/1472-6963-9197 PMID:19874590

11. Raciborska DA, Hernández P, Glassman A. Accounting for health spending in developing countries. Health Aff (Millwood). 2008 Sep-Oct;27(5):1371-80. http://dx.doi.org/10.1377/hlthaff.27.5.1371 PMID:18780927

12. De S, Dmytraczenko T, Brinkerhoff D, Tien M. Has improved availability of health expenditure data contributed to evidence-based policymaking? Country experiences with National Health Accounts. Partners for Health Reformplus; 2003 (http:// www.phrplus.org/Pubs/Techo22_fin.pdf, accessed 30 Janaury 2020).

13. El-Jardali F, Lavis JN, Ataya N, Jamal D, Ammar W, Raouf S. Use of health systems evidence by policymakers in Eastern Mediterranean countries: views: practices and contextual influences. BMC Health Serv Res. 2012;12:200. https://doi.org/10.1186/14726963-12-200

14. Health Accounts country platform approach [website]. World Health Organization (http://www.who.int/health-accounts/platform_approach/en/, accessed 30 January 2020).

15. How have Health Accounts data been used to influence policy? Health Accounts impacted policy in over 30 countries worldwide. Health Finance \& Governance; 2018 (https://www.hfgproject.org/wp-content/uploads/2018/05/Resource_Tracking_Brief_Map. pdf, accessed 30 January 2020).

16. World Health Statistics 2010. Geneva: World Health Organization; 2010 (https://www.who.int/whosis/whostat/2010/en/, accessed 30 January 2020).

17. El-Jardali F, Jamal D, Jaafar M, Rahal Z. Analysis of health professionals migration: a two-country case study for the United Arab Emirates and Lebanon. Geneva: World Health Organization, Geneva; 2008 (https://www.who.int/hrh/migration/Case_study_ UAE_Lebanon_2008.pdf, accessed 30 January 2020).

18. Fogarty L, Kim YM, Juon H-S, Tappis H, Noh JW, Zainullah P, et al. Job satisfaction and retention of health-care providers in Afghanistan and Malawi. Hum Resour Health. 2014;12:Article number 11. https://doi.org/10.1186/1478-4491-12-11

19. Waldman R, Hanif H. The public health system in Afghanistan: current issues. Kabul: Afghanistan Research and Evaluation Unit; 2002.

20. Rahim HFA, Sibai A, Khader Y, Hwalla N, Fadhil I, Alsiyabi H, Husseini A, et al. Non-communicable diseases in the Arab world. The Lancet. 2014 Jan 25;383(9914):356-67. https://doi.org/10.1016/S0140-6736(13)62383-1 PMID:24452044

21. Heller PS. The prospects of creating fiscal space for the health sector. Health Policy Plan. 2006 Mar;21(2):75-9. http://dx.doi. org/10.1093/heapol/czjo13 PMID:16415338

22. Asbu EZ, Masri MD, Kaissi A. Health status and health systems financing in the MENA region: roadmap to universal health coverage. Global Health Res Policy. 2017 Sep 4;2(1):25. https://doi.org/10.1186/s41256-017-0044-9 PMID:29202093

23. Xu K, Soucat A, Kutzin J, et al. New perspectives on global health spending for universal health coverage. Geneva: World Health Organization; 2018 (WHO/HIS/HGF/ HFWorkingPaper/18.2; https://apps.who.int/iris/bitstream/handle/10665/259632/WHOHIS-HGF-HFWorkingPaper-17.10-eng.pdf?sequence=1, accessed 30 January 2020).

24. National health accounts conclusions and implications Djibouti. World Bank; 2000 (http://siteresources.worldbank.org/ INTHSD/Resources/376278-1261143298590/6660179-1280173228245/DjiboutiNHA.pdf accessed 30 January 2020).

25. Sabri, B. Healthcare financing in the African Countries of the Eastern Mediterranean. Int Soc Security Rev. 2003; 56:73-85. http://dx.doi.org/10.1111/1468-246X.00170

26. Kazemi Karyani A, Homaie Rad E, Pourreza A, Shaahmadi F. Democracy, political freedom and health expenditures: evidence from Eastern Mediterranean countries. Int J Hum Rights Healthcare. 2015;8(3):187-94. https://doi.org/10.1108/ IJHRH-01-2015-0001 


\section{Appendix}

\section{Questionnaire:}

NAME OF COUNTRY......

\section{PART ONE}

1. What is the health accounting methodology used? (SHA 1.0/SHA 2011/SHA 2011 with disease/any other)

2. When was the last NHA exercise done?

a. Approximately how much time does it take for the production and dissemination of results of HA? |_l_| months

b. Approximately how much time does it take for analysis and use of HA? |_l__ months

3. How many NHA exercises have been done so far?

4. How many years of NHA data are available? (SHA 1.o/SHA 2011/SHA 2011 with disease/any other) |_L_

5. Who paid the cost of the last NHA?
a. Government
b. Development partner or donor
c. Part government part donor

i. If the government met the cost fully or in part, was it provided through governmental budget? How much and what proportion of total cost?

6. Were any other sources of support provided for the production of HA?

7. What is the total number of staff that worked on the last NHA? How long have they been working?
a. Number of full-time staff
b. Number of full-year part-time staff
c. Number of part-year part-time staff
d. Number of full-time consultants
e. Number of part-time consultants

8. What is the institute or department of staff (the team of NHA)

9. Has the most current NHA helped you identify any need for additional spending on health and the potential fiscal space areas that could help meet this identified need? (Ask to elaborate more in strengths or weakness section)

\section{PART TWO}

\section{STRENGTHS/SUCCESSES:}

1. To what do you attribute the successes in the production of HA?

a. How does your government's commitment to the production of NHA play a part in the success?

b. Was the NHA activity institutionalized?

c. How are data efficiently collected? 
d. Have you standardized the method for data collection, reporting and analysis?

How data from household surveys are used, e.g., is adjustment made for possible underestimation of PHE?

e. Can you elaborate on how financial resources or other support helped implement your NHA?

f. How were NHA results successfully translated into reports that met your country's policy goals?

g. Did the NHA finding affect the policy-makers' decision? If yes, how?

h. Does the NHA team have access to microdata of household survey?

\section{WEAKNESSES/CHALLENGES:}

2. What were some challenges that you faced in the production of HA?

a. How do you make sure the data collected are effectively disseminated and translated?

b. Has there ever been a reason why data collection for NHA was problematic?

3. Has your country been having any difficulties in using HAPT?

4. What is the top health sector weakness according to your most recent HA?

a. What do you think can contribute to resolving this weakness?

i. More commitment from the government.

ii. More funding

iii. Better institutionalization of staff.

5. Does the capacity building on how to implement NHA as a source of information used on a daily basis a challenge in your country?

6. Have there been any recent sociocultural or socioeconomic changes that could have potentially affected the latest NHA data?

7. How did your department coordinate and collaborate to produce primary and secondary data?

\section{OPPORTUNITIES:}

8. What opportunities has the production of NHA been able to provide to the country?

9. Are there any current trends that you feel could affect the country's HA? (Could be either threat or opportunity)

a. (If opportunity) What specifically may benefit as a result: demand and use, production, dissemination, or translation of data?

b. (If threat) In what way does this concern you about the future of your country's NHA?

10. Are there any new technologies that you would like to implement in the future, but are currently unable to do so? 
11. Do you think data found about generational shifts could affect future NHA? (Could be threat or opportunity depending on answer)

a. In what way?

\section{THREATS:}

12. What are some of the threats that the production of NHA have brought to the government's attention?

13. Is there anything specific that could be a risk to your country's sustainability of NHA?

a. In what way will this affect how it is translated into policy?

b. Will it affect future data collection?

\section{PRIORITIES:}

From your recent NHA, what did you find to be priorities that needed to be addressed?

c. How is your country is dealing with this or plans to do so if not already?

d. If it is something that has not been able to be addressed, why?

Is there anything else that you would like to add about the successes or challenges of HA your country has faced thus far?

\begin{tabular}{|c|c|c|c|c|c|c|}
\hline Challenges & Turnover & Data collection & Quality of data & $\begin{array}{l}\text { SHA } 2011 \text { or } \\
\text { HAPT }\end{array}$ & $\begin{array}{l}\text { Lack of funding } \\
\text { or government } \\
\text { commitment }\end{array}$ & $\begin{array}{c}\text { Political or } \\
\text { geographical } \\
\text { problems }\end{array}$ \\
\hline Countries & $\begin{array}{l}\text { Afghanistan, } \\
\text { Djibouti, Iraq, } \\
\text { Lebanon, Saudi } \\
\text { Arabia, Sudan, } \\
\text { UAE, Yemen }\end{array}$ & $\begin{array}{l}\text { Afghanistan, } \\
\text { Bahrain, Djibouti, } \\
\text { Egypt, Lebanon, } \\
\text { Palestine, Saudi } \\
\text { Arabia, Yemen }\end{array}$ & $\begin{array}{l}\text { Bahrain, Djibouti, } \\
\text { Palestine, Saudi } \\
\text { Arabia, Yemen }\end{array}$ & $\begin{array}{l}\text { Afghanistan, } \\
\text { Djibouti, Jordan, } \\
\text { Iran, Morocco, } \\
\text { Pakistan, Saudi } \\
\text { Arabia }\end{array}$ & $\begin{array}{l}\text { Afghanistan, } \\
\text { Libya, Somalia, } \\
\text { Sudan, Syria, } \\
\text { Yemen }\end{array}$ & $\begin{array}{c}\text { Jordan, Libya, } \\
\text { Palestine, Somalia, } \\
\text { Syria }\end{array}$ \\
\hline
\end{tabular}

SHA = System of Health Accounts; HAPT = Health Accounts Production Tool; UAE = United Arab Emirates.

\begin{tabular}{|c|c|c|c|c|c|c|c|c|c|}
\hline & AFG & BAH & DJI & EGY & IRA & IRQ & JOR & LEB & LIY \\
\hline $\begin{array}{l}\text { Responsible } \\
\text { institution }\end{array}$ & $\mathrm{MOH}$ & $\mathrm{MOH}$ & $\mathrm{MOH}$ & $\mathrm{MOH}$ & $\mathrm{MOH}$ & $\mathrm{MOH}$ & $\begin{array}{l}\text { High Health } \\
\text { Council }\end{array}$ & $\mathrm{MOH}$ & $\mathrm{MOH}$ \\
\hline \multirow[t]{2}{*}{$\begin{array}{l}\text { Funding } \\
\text { source }\end{array}$} & $\begin{array}{l}\text { MOH, } \\
\text { Donors }\end{array}$ & $\begin{array}{c}\text { Govt } \\
\text { budget }\end{array}$ & $\begin{array}{l}\text { Govt budget, } \\
\text { Donors }\end{array}$ & $\mathrm{MOH}$ & $\mathrm{MOH}$ & Govt budget & Govt budget & $\begin{array}{l}\text { Govt budget, } \\
\text { Donors }\end{array}$ & $\begin{array}{c}\text { Govt } \\
\text { budget }\end{array}$ \\
\hline & MOR & OMA & PAK & PSE & SAA & SUD & SYR & TUN & UAE \\
\hline $\begin{array}{l}\text { Responsible } \\
\text { institution }\end{array}$ & $\mathrm{MOH}$ & $\mathrm{MOH}$ & PBS & PCBS & $\begin{array}{c}\text { Supreme } \\
\text { Council }\end{array}$ & $\mathrm{MOH}$ & $\mathrm{MOH}$ & $\mathrm{MOH}$ & $\mathrm{MOH}$ \\
\hline $\begin{array}{c}\text { Funding } \\
\text { source }\end{array}$ & $\begin{array}{l}\text { MOH, } \\
\text { WHO }\end{array}$ & $\begin{array}{c}\text { Govt } \\
\text { budget }\end{array}$ & Govt budget & $\begin{array}{l}\text { Govt budget, } \\
\text { Donors }\end{array}$ & $\begin{array}{l}\text { Govt } \\
\text { budget }\end{array}$ & $\begin{array}{l}\text { Govt budget, } \\
\text { Donors }\end{array}$ & $\begin{array}{l}\text { Govt budget, } \\
\text { Donors }\end{array}$ & Govt budget & $\begin{array}{c}\text { Govt } \\
\text { budget }\end{array}$ \\
\hline
\end{tabular}

AFG = Afghanistan; BAH = Bahrain; DJI = Djibouti; EGY = Egypt; IRA = Islamic Republic of Iran; JOR = Jordan; LEB = Lebanon; MOR = Morocco; OMA = Oman; PAK = Pakistan; PSE = Palestine; SAA = Saudi Arabia; SUD = Sudan; SYR = Syrian Arab Republic; TUN = Tunisia; $M O H=$ Ministry of health; PBS = Pakistan Bureau of Statistics; PCBS = Palestine Central Bureau of Statistics; WHO $=$ World Health Organization.

List of countries that attended Regional Health Account Training Workshop: Afghanistan, Bahrain, Egypt, Islamic Republic of Iran, Iraq, Jordan, Lebanon, Libya, Morocco, Oman, Palestine, Saudi Arabia 